\title{
Effect of Dietary Vitamin C and Corn Oil Supplementation on Broiler Performance under Heat Stress
}

\author{
M. I. Alshelmani ${ }^{*}$, N. A. Salem ${ }^{1}$, A. A. Salim ${ }^{2}$ and Ibrahim D. A. Sakal ${ }^{3}$ \\ ${ }^{1}$ Department of Animal Production, Faculty of Agriculture, University of Benghazi, \\ Benghazi, Libya \\ .${ }^{2}$ Department of Animal Production, Faculty of Agriculture, University of Tripoli, \\ Tripoli, Libya \\ ${ }^{3}$ Department of Zoology, Faculty of Science, University of Al-zawia, Al-zawia, Libya \\ *Corresponding author
}

\begin{abstract}
A B S T R A C T
Four feeding trials were conducted to investigate the influence of vitamin $\mathrm{C}$ and corn oil supplementation on broiler performance under heat stress. In the first and second experiments, a total of 180 one-day broiler chicks were randomly distributed into three groups. The chicks were raised on open house system during summer season. The birds were fed three levels of vitamin C; 0,500 and $1000 \mathrm{mg} / \mathrm{kg}$ diet, respectively (experiment 1 ), and corn oil; $0 \%, 3 \%$ and $5 \%$, respectively (experiment 2 ). The two trials were lasted to 8 weeks. In experiment 3, a total of 180 three-week old broiler chickens were randomly distributed into six combination treatments in environmental chambers at $24^{\circ} \mathrm{C}$ and constant $35^{\circ} \mathrm{C}$. The birds fed diet supplemented with $0 \%, 5 \%$ corn oil and $5 \%$ corn oil with $500 \mathrm{mg} / \mathrm{kg}$ diet, respectively. In the fourth experiment, the broiler chickens were randomly distributed into six combination treatments as mentioned in the $3^{\text {rd }}$ trial. The birds were fed diet supplemented with $500 \mathrm{mg}$ vitamin $\mathrm{C} / \mathrm{kg}$ diet, $3 \%$ corn oil and 3\% corn oil with vitamin $\mathrm{C}$, respectively. The experiment was lasted to five weeks. Feed intake, body weight gain, and feed conversion ratio were measured. The findings showed that high ambient temperature had negative effect $(\mathrm{P}<0.05)$ on broiler performance. The supplementation of vitamin $\mathrm{C}$ or corn oil led to a significant improvement $(\mathrm{P}<0.05)$ in broiler performance. In general, the supplementation of corn oil or vitamin $\mathrm{C}$ improved the BWG and FCR for those birds raised under heat stress.
\end{abstract}

\section{Introduction}

The high ambient temperature may lead to decrease the broiler performance. The high temperature leads to reduce feed intake (FI) and body weight (BW) (Rafiee et al., 2016;
Al-Sultan et al., 2019) as well as body weight gain (BWG) for broiler chickens under cyclic high temperature (Attia et al., 2017), and constant high temperature (Zeferino et al., 2016). In addition, the temperature may reduce the feed conversion ratio (FCR) (Attia 
et al., 2017; Al-Sultan et al., 2019). It is also lead to increase the level of corticosterone hormone in blood (Rafiee et al., 2016).

The studies showed that supplementation of vitamin $\mathrm{C}$ or corn oil to broiler diets under heat stress may alleviate the negative effects of high temperature. It was mentioned by (Rafiee et al., 2016; Attia et al., 2017; AlSultan et al., 2019)that FI and BWG were improved in broiler chickens raised on high constant temperature when fed diet supplemented by vitamin $\mathrm{C}$.

In addition, the productive performance could be improved for those birds fed diet containing high levels of vegetable oil. It was reported by (Pesti and Smith, 1984; Hussein, 1996) that FI, BWG and FCR were improved in broilers fed diet containing high levels of vegetable oil under heat stress. Since the supplementation of corn oil or vitamin $\mathrm{C}$ have beneficial effects under heat stress (Hussein, 1996), the objective of the current study was to investigate the influence of supplementation vitamin $\mathrm{C}$ and corn oil together to broiler diet under heat stress.

\section{Materials and Methods}

Four feeding trials were conducted at the Poultry Research Center, Faculty of Agriculture, University of Tripoli, Libya. In the first two experiments, a total of 180 oneday old broiler chickens (Shiver) were purchased from local hatchery and raised for eight weeks. The birds were wing-banded, weighed and randomly distributed into six dietary treatments.

Each treatment was divided into three replicates with 10 birds each. The birds were fed basal diets based on NRC (1994) recommendation (Table 1), and supplemented with 0,500 and $1000 \mathrm{mg}$ vitamin/ $\mathrm{kg}$ diet, respectively (experiment 1), and $0 \%, 3 \%$ and
$5 \%$ corn oil, respectively (experiment 2 ). The birds were randomly distributed as mentioned previously.

The birds were raised in an open house system during summer season (August and September). The temperature was measured twice a day ( 8.00 am and $1.00 \mathrm{pm})$ inside and outside the building. The average temperature was $31^{\circ} \mathrm{C}$ and $29.50^{\circ} \mathrm{C}$ inside and outside the building, respectively.

In the third experiment, a total of 180 threeweek old broiler chickens (Shiver) were individually weighed and randomly distributed into six combination treatments with six replicates and five birds each. The birds were fed basal diet supplemented with $0 \%, 5 \%$ corn oil and $5 \%$ corn oil with $500 \mathrm{mg}$ vitamin $\mathrm{C} / \mathrm{kg}$ diet, respectively. The same procedures were applied for the $4^{\text {th }}$ experiment.

However, the birds were fed basal diet supplemented with $500 \mathrm{mg}$ vitamin C, 3\% corn oil or $3 \%$ corn oil with $500 \mathrm{mg}$ vitamin $\mathrm{C} / \mathrm{kg}$ diet. The $1^{\text {st }}$ and $2^{\text {nd }}$ experiments were lasted to eight weeks, whereas, the $3^{\text {rd }}$ and $4^{\text {th }}$ experiments were lasted to five weeks. FI, BWGand FCR were measured and calculated. All birds were vaccinated against Gumboro and Newcastle diseases at 14 and 21 day, respectively as described by (Alshelmani et al., 2017).

\section{Statistical analysis}

Data were analyzed using completely randomized design in the $1^{\text {st }}$ and $2^{\text {nd }}$ experiment, whereas factorial completely randomized design was applied for the $3^{\text {rd }}$ and $4^{\text {th }}$ experiment. The procedure was done by statistical analysis software (SAS, 2003). The differences between the treatments were separated and compared by Duncane multiple range test at significant level at 0.05 . 


\section{Results and Discussion}

Table 2 shows the broiler performance in experiment 1 . The supplementation of vitamin $\mathrm{C}$ to a significant improvement $(\mathrm{P}<0.05)$ on FI, BWG and FCR. On the other hand, no significant differences $(\mathrm{P}>0.05)$ were observed in comparison between the two levels of vitamin $\mathrm{C}$ on broiler diet. The positive improvement on broiler performance could be attributed to the compensation of vitamin $\mathrm{C}$ levels in their bodies as a result of high temperature. These findings are consistent with (Pardue et al., 1985; Pardue and Thaxton, 1986; McKee and Harrison, 1995; McKee et al., 1997), who reported vitamin $\mathrm{C}$ supplementation led to minimize the negative effects in broiler chickens under heat stress.

The effect of corn oil on broiler performance is shown in Table 3. The addition of $3 \%$ or $5 \%$ corn oil to broiler diets led to a positive improvement $(\mathrm{P}<0.05)$ in $\mathrm{BWG}$ and FCR.

Table.1 Ingredients of basal diet and nutrient composition

\begin{tabular}{|c|c|c|c|}
\hline Ingredient (\%) & \multicolumn{2}{|c|}{ Corn oil (\%) } & \\
\cline { 2 - 4 } & 0 & 3 & 5 \\
\hline Yellow corn & 65.000 & 57.815 & 51.500 \\
\hline Soybean meal (44) & 30.816 & 33.550 & 34.500 \\
\hline Wheat bran & 0 & 1.500 & 4.930 \\
\hline Corn oil & 0 & 3.000 & 5.000 \\
\hline Dicalcium phosphate & 1.818 & 1.775 & 1.730 \\
\hline Limestone & 1.330 & 1.340 & 1.340 \\
\hline Iodized salt & 0.300 & 0.300 & 0.300 \\
\hline Vitamin and minerals premix $\mathbf{1}^{1}$ & 0.500 & 0.500 & 0.500 \\
\hline DL-methionine & 0.236 & 0.220 & 0.200 \\
\hline Total & 100.000 & 100.000 & 100.000 \\
\hline & Calculated analysis $(\%)$ & \\
\hline Metabolizable energy (kcal/ kg) & 2873.83 & 3001.76 & 3048.05 \\
\hline Crude protein & 19.22 & 20.04 & 20.43 \\
\hline Calcium & 1.00 & 1.00 & 1.00 \\
\hline Phosphorus & 0.46 & 0.46 & 0.45 \\
\hline Lysine & 1.07 & 1.15 & 1.16 \\
\hline Methionine + Cystine & 0.90 & 0.90 & 0.90 \\
\hline Protein: Energy ratio & $1: 149.52$ & $1: 149.78$ & $1: 149.20$ \\
\hline Tay
\end{tabular}

${ }^{1}$ The vitamin and mineral premix provided per kg of diet: vitamin A, 4000000 IU; vitamin D3, 833333 IU; vitamin E $6666 \mathrm{mg}$; vitamin K3, $666 \mathrm{mg}$; vitamin B1, $666 \mathrm{mg}$; vitamin B2, $1666 \mathrm{mg}$; vitamin B6, $1000 \mathrm{mg}$; vitamin B12 5 mg, Folic acid, $33.3 \mathrm{mg}$; Biotin, $17 \mathrm{mg}$; Iron, 10 ; Copper, 2.167; Zinc, 18.334; Manganese 20.0; Iodine, 0.167; Cobalt, 0.034 and Selenium, 0.034 . 
Table.2 Effect of vitamin C supplementation $(\mathrm{mg} / \mathrm{kg}$ diet) on feed intake, body weight gain and feed conversion ratio in experiment $1 *$

\begin{tabular}{|c|c|c|c|}
\hline $\begin{array}{c}\text { Vitamin C (mg/ kg } \\
\text { diet) }\end{array}$ & Feed intake (g) & BWG $^{\mathbf{1}}(\mathbf{g})$ & $\begin{array}{c}\text { FCR }^{\mathbf{2}}(\mathbf{g} \text { Feed:g } \\
\text { Gain) }\end{array}$ \\
\hline $\mathbf{0}$ & $4913.28 \pm 75.09^{\mathrm{a}}$ & $2204.88 \pm 25.35^{\mathrm{a}}$ & $2.05 \pm 0.14^{\mathrm{a}}$ \\
\hline $\mathbf{5 0 0}$ & $5402.00 \pm 89.62^{\mathrm{b}}$ & $2627.04 \pm 32.89^{\mathrm{b}}$ & $1.84 \pm 0.13^{\mathrm{b}}$ \\
\hline $\mathbf{1 0 0 0}$ & $5502.72 \pm 89.52^{\mathrm{b}}$ & $2590.96 \pm 33.08^{\mathrm{b}}$ & $1.93 \pm 0.14^{\mathrm{b}}$ \\
\hline
\end{tabular}

*Mean \pm SE. ${ }^{a, b}$ values with different superscript in the same column are significantly different $(\mathrm{P}<0.05)$.

${ }^{1}$ BWG: Body weight gain

${ }^{2}$ FCR: Feed conversion ratio

Table.3 Effect of added corn oil on feed intake, body weight gain and feed conversion ratio in experiment $2^{*}$

\begin{tabular}{|c|c|c|c|}
\hline Corn oil (\%) & Feed intake (g) & BWG $^{\mathbf{1}}(\mathbf{g})$ & $\begin{array}{c}\text { FCR }^{\mathbf{2}} \\
\text { (g Feed:g Gain) }^{\text {(g) }}\end{array}$ \\
\hline $\mathbf{0}$ & $4913.28 \pm 75.09^{\mathrm{a}}$ & $2204.88 \pm 25.35^{\mathrm{a}}$ & $2.05 \pm 0.14^{\mathrm{a}}$ \\
\hline $\mathbf{3}$ & $5088.00 \pm 79.40^{\mathrm{b}}$ & $2444.56 \pm 26.24^{\mathrm{b}}$ & $1.87 \pm 0.15^{\mathrm{b}}$ \\
\hline $\mathbf{5}$ & $5098.40 \pm 89.15^{\mathrm{b}}$ & $2651.20 \pm 32.84^{\mathrm{b}}$ & $1.73 \pm 0.13^{\mathrm{b}}$ \\
\hline
\end{tabular}

*Mean \pm SE. ${ }^{a, b}$ values with different superscript in the same column are significantly different $(\mathrm{P}<0.05)$.

${ }^{1}$ BWG: Body weight gain

${ }^{2}$ FCR: Feed conversion ratio

Table.4 Effect of ambient temperature, vitamin $\mathrm{C}$ and corn oil on feed intake, body weight gain and feed conversion ratio in experiment $3 *$

\begin{tabular}{|c|c|c|c|c|c|}
\hline \multicolumn{3}{|c|}{ Treatments } & \multirow[b]{2}{*}{ Feed intake (g) } & \multirow[b]{2}{*}{$\mathrm{BWG}^{1}(\mathrm{~g})$} & \multirow{2}{*}{$\begin{array}{c}\mathrm{FCR}^{2}(\mathrm{~g} \\
\text { Feed: g Gain) }\end{array}$} \\
\hline $\begin{array}{l}\text { Temperature ( } \\
{ }^{\circ} \mathrm{C} \text { ) }\end{array}$ & $\begin{array}{c}\text { Vitamin C (mg/ } \\
\text { kg diet) }\end{array}$ & $\begin{array}{l}\text { Corn oil } \\
(\%)\end{array}$ & & & \\
\hline \multirow[t]{3}{*}{24} & 0 & 0 & $4580.85 \pm 34.68^{a}$ & $2134.00 \pm 14.34^{\mathrm{a}}$ & $2.21 \pm 0.12^{\mathrm{a}}$ \\
\hline & 0 & 5 & $4542.10 \pm 32.65^{\mathrm{a}}$ & $2417.65 \pm 18.56^{b}$ & $1.99 \pm 0.13^{\mathrm{ab}}$ \\
\hline & 500 & 5 & $4432.00 \pm 36.24^{a}$ & $2515.85 \pm 16.03^{b}$ & $1.81 \pm 0.11^{\mathrm{b}}$ \\
\hline \multirow[t]{3}{*}{35} & 0 & 0 & $2581.90 \pm 18.82^{b}$ & $1140.85 \pm 20.33^{c}$ & $2.60 \pm 0.20^{\mathrm{a}}$ \\
\hline & 0 & 5 & $2658.00 \pm 27.00^{b}$ & $1416.40 \pm 22.41^{d}$ & $2.01 \pm 0.12^{\mathrm{ad}}$ \\
\hline & 500 & 5 & $2855.90 \pm 18.69^{c}$ & $1656.50 \pm 17.75^{\mathrm{e}}$ & $1.85 \pm 0.10^{\mathrm{bd}}$ \\
\hline
\end{tabular}

*Mean \pm SE. ${ }^{\text {a-e }}$ values with different superscript in the same column are significantly different $(\mathrm{P}<0.05)$.

${ }^{1}$ BWG: Body weight gain

${ }^{2}$ FCR: Feed conversion ratio 
Table.5 Effect of ambient temperature, vitamin C and corn oil on feed intake, body weight gain, feed conversion ratio in experiment $4 *$

\begin{tabular}{|c|c|c|c|c|c|}
\hline \multicolumn{3}{|c|}{ Treatments } & \multirow[b]{2}{*}{$\begin{array}{c}\text { Feed intake } \\
\text { (g) }\end{array}$} & \multirow[b]{2}{*}{$\mathrm{BWG}^{\mathrm{l}}(\mathrm{g})$} & \multirow[b]{2}{*}{$\begin{array}{c}\text { FCR }^{2}(\mathrm{~g} \\
\text { Feed: g Gain) }\end{array}$} \\
\hline $\begin{array}{l}\text { Temperature } \\
\left({ }^{\circ} \mathrm{C}\right)\end{array}$ & $\begin{array}{c}\text { Vitamin C (mg/ } \\
\text { kg diet) }\end{array}$ & $\begin{array}{l}\text { Corn oil } \\
(\%)\end{array}$ & & & \\
\hline \multirow[t]{3}{*}{24} & 500 & 0 & $\begin{array}{c}3932.80 \pm \\
29.05^{\mathrm{a}}\end{array}$ & $\begin{array}{c}1961.00 \pm \\
16.00^{\mathrm{a}}\end{array}$ & $2.07 \pm 0.10^{\mathrm{a}}$ \\
\hline & 0 & 3 & $\begin{array}{c}3908.25 \pm \\
27.48^{\mathrm{a}}\end{array}$ & $\begin{array}{c}1984.95 \pm \\
12.88^{\mathrm{a}}\end{array}$ & $2.00 \pm 0.08^{\mathrm{a}}$ \\
\hline & 500 & 3 & $\begin{array}{c}3817.10 \pm \\
34.30^{\mathrm{a}}\end{array}$ & $\begin{array}{c}1970.10 \pm \\
17.66^{\mathrm{a}}\end{array}$ & $1.99 \pm 0.10^{\mathrm{a}}$ \\
\hline \multirow[t]{3}{*}{35} & 500 & 0 & $\begin{array}{c}2337.30 \pm \\
16.40^{\mathrm{b}}\end{array}$ & $\begin{array}{c}943.00 \pm \\
14.14^{\mathrm{b}}\end{array}$ & $2.92 \pm 0.19^{b}$ \\
\hline & 0 & 3 & $\begin{array}{c}2323.90 \pm \\
16.47^{\mathrm{b}}\end{array}$ & $\begin{array}{c}1136.65 \pm \\
12.12^{c}\end{array}$ & $2.23 \pm 0.16^{\mathrm{a}}$ \\
\hline & 500 & 3 & $\begin{array}{c}2356.60 \pm \\
22.27^{\mathrm{b}}\end{array}$ & $\begin{array}{c}1192.40 \pm \\
16.33^{\mathrm{c}}\end{array}$ & $1.19 \pm 0.15^{\mathrm{a}}$ \\
\hline
\end{tabular}

$*$ Mean \pm SE. ${ }^{\text {a-e }}$ values with different superscript in the same column are significantly different $(\mathrm{P}<0.05)$.

${ }^{1}$ BWG: Body weight gain; ${ }^{2}$ FCR: Feed conversion ratio

The effect of vitamin $\mathrm{C}$ and corn oil on broilers under heat stress is presented in table 4. The high temperature was negatively affected $(\mathrm{P}<0.05)$ broiler performance. There was improvement $(\mathrm{P}<0.05)$ in FI for those birds fed diet supplemented by $5 \%$ corn oil with $500 \mathrm{mg}$ vitamin $\mathrm{C} / \mathrm{kg}$ diet under heat stress.

There was significant improvement $(\mathrm{P}<0.05)$ in BWG and FCR for those birds fed diet supplemented with $5 \%$ corn oil with or without vitamin $\mathrm{C}$ at $24^{\circ} \mathrm{C}$ or $35^{\circ} \mathrm{C}$. Birds fed diet supplemented with corn oil with vitamin $\mathrm{C}$ showed better $(\mathrm{P}<0.05) \mathrm{FI}$ and $\mathrm{BWG}$ under heat stress. Table 5 shows the effect of diet supplemented with corn oil and vitamin $\mathrm{C}$ on broiler performance under heat stress.

The high temperature was negatively affected $(\mathrm{P}<0.05)$ broiler performance. There was significant improvement $(\mathrm{P}<0.05)$ in $\mathrm{BWG}$ and FCR for those birds fed diet supplemented with $3 \%$ corn oil with or without vitamin $\mathrm{C}$ at $24^{\circ} \mathrm{C}$ or $35^{\circ} \mathrm{C}$. The positive improvement in broiler performance for birds fed diet supplemented with corn oil (experiment 2,3 and 4) could be attributed to the energy utilization and decrease of heat increment (Rafiei-Tari et al., 2018).

These findings are in agreement with (Mateos and Sell, 1981; Hussein, 1996), who mentioned that feeding diet containing high levels of vegetable oil can improve broiler performance under heat stress. The synergistic effect of vitamin $\mathrm{C}$ and corn oil may play an important role to alleviate heat stress on broiler which positively reflected in their performance.

\section{References}

Al-Sultan, S., Abdel-Raheem, S., Abd-Allah, S., and Edris, A. 2019. Alleviation of chronic heat stress in broilers by dietary supplementation of novel feed additive combinations. Slovenian Veterinary 
Research, 56.

Alshelmani, M. I., Loh, T. C., Foo, H. L., Sazili, A. Q., and Lau, W. H. 2017. Effect of feeding different levels of palm kernel cake fermented by Paenibacillus polymyxa ATCC 842 on broiler growth performance, blood biochemistry, carcass characteristics, and meat quality. Animal Production Science 57:839-848.

Attia, Y. A., Al-Harthi, M. A., El-Shafey, A. S., Rehab, Y. A., and Kim, W. K. 2017. Enhancing tolerance of broiler chickens to heat stress by supplementation with vitamin $\mathrm{E}$, vitamin $\mathrm{C}$ and/or probiotics. Annals of Animal Science, 17:11551169.

Hussein, A. 1996. Effects of dietary energy and vitamin $\mathrm{C}$ on growth performance of broiler chicks raised in hot climates. Emirates Journal of Food and Agriculture, Pp. 49-62.

Mateos, G. G., and Sell, J. L. 1981. Nature of the extrametabolic effect of supplemental fat used in semipurified diets for laying hens. Poultry Science, 60:1925-1930.

McKee, J., and Harrison, P. 1995. Effects of supplemental ascorbic acid on the performance of broiler chickens exposed to multiple concurrent stressors. Poultry Science, 74:17721785 .

McKee, J., Harrison, P., and Riskowski, G. 1997. Effects of supplemental ascorbic acid on the energy conversion of broiler chicks during heat stress and feed withdrawal. Poultry Science, 76:12781286.
NRC. 1994. Nutrient Requirements of Poultry (9th Rev. Ed.). National Academy Press, Washington, DC.

Pardue, S., and Thaxton, J. P. 1986. Ascorbic acid in poultry: a review. World's Poultry Science Journal, 42: 107-123.

Pardue, S., Thaxton, J. P., and Brake, J. 1985. Influence of supplemental ascorbic acid on broiler performance following exposure to high environmental temperature. Poultry Science, 64:13341338.

Pesti, G., and Smith, C. 1984. The response of growing broiler chickens to dietary contents of protein, energy and added fat. British Poultry Science 25:127-138.

Rafiee, F., Mazhari, M., Ghoreishi, M., and Esmaeilipour, O. 2016. Effect of lemon verbena powder and vitamin $\mathrm{C}$ on performance and immunity of heat- stressed broilers. Journal of Animal Physiology and Animal Nutrition, 100: 807-812.

Rafiei-Tari, A., Sadeghi, A., and Mousavi, S. 2018. Effect of vegetable oil supplementation on hepatic patolohgy and liver PPAR $\gamma$ gene expression in broiler chickens exposed to heat stress. Livestock Science, 9:70-74.

SAS. 2003. Statistical analytical system. SAS Institute Inc., Cary, NC, USA.

Zeferino, C., Komiyama, C., Pelícia, V., Fascina, V., Aoyagi, M., Coutinho, L. L., Sartori, J., and Moura, A. 2016. Carcass and meat quality traits of chickens fed diets concurrently supplemented with vitamins $\mathrm{C}$ and $\mathrm{E}$ under constant heat stress. Animal, 10:163-171.

\section{How to cite this article:}

Alshelmani, M. I., N. A.Salem, A. A. Salim and Sakal, I. 2020. Effect of Dietary Vitamin C and Corn Oil Supplementation on Broiler Performance under Heat Stress. Int.J.Curr.Microbiol.App.Sci. 9(04): 225-230. doi: https://doi.org/10.20546/ijcmas.2020.904.027 